\title{
UNIVERSITIES AND INCUBATORS: KEY ENTREPRENEURSHIP AND SOCIOECONOMIC DEVELOPMENT DRIVING FACTORS
}

\author{
Liane Mahlmann Kipper \\ University of Santa Cruz do Sul, Brazil \\ E-mail: liane@unisc.br \\ Evandro Rodrigues \\ University of Santa Cruz do Sul, Brazil \\ E-mail: evanddro@gmail.com \\ Aline Graziele Ferrari \\ University of Santa Cruz do Sul, Brazil \\ E-mail: alineferrari@mx2.unisc.br \\ Bruna Bueno Mariani \\ University of Santa Cruz do Sul, Brazil \\ E-mail: brunamariani@mx2.unisc.br
}

Submission: 10/02/2014

Revision: 07/03/2014

Accept: 10/04/2014

\section{ABSTRACT}

Economic diversification is an utterly important factor for regions that are directly or indirectly related to any productive mechanisms and seek to strengthen their foundations for the generation of jobs and income. Within this context, to invest in business preparation and maturation, especially in the ones related to the technological area, turns out to be an interesting mean of diversifying a regional economy that is facing the risk of stagnation. This study considers the importance of the role taken on by universities and their incubators in driving entrepreneurship and supporting the creation of new companies and the innovative capacity of a country through knowledge transfer amongst universities and companies, generating benefits and socioeconomic progress. It also conducts a case study on a company of the information technology area, recently incubated and whose major objective consists in becoming part of this economic diversification basis. 
DOI: 10.14807/ijmp.v5i4.208

Keywords: socioeconomic development, entrepreneurship, incubation process, universities - businesses

\section{INTRODUCTION}

Economic diversification may be taken as a decisive factor for any country willing to keep constantly growing, especially if the characteristics of constant changes and uncertainties in the global economic scenario are analyzed. Therefore, any initiatives that seek this diversification deserve praise. Within this context, according to Viana (2012), there is need for coming up with a solution to avoid dilemmas stemming from a fragile position, consciously analyzing the future scenarios to which the company is submitted in the Brazilian and global market, the simulation of possible changes in the market, competition and macro-economic environments.

According to Matíz and Naranjo (2010), entrepreneurship and the creation of companies are viewed as major strategies to define the existing policies geared towards socioeconomic development.

In this context and according to Birgitta, et al. (2013), by creating and developing new technologies and markets, entrepreneurship carries vital importance in promoting economic development and growth. Companies with higher turnover, growth and high level of knowledge are the ones that demonstrate an innovative behavior (FRANCO; HAASE, 2013).

It is worth noting that private initiatives have been part of this process together with universities and government promoting innovation and entrepreneurship. Therefore the interaction among universities and companies is defined by linking the scientific knowledge source and the part responsible for applying such knowledge. The main role of educational and technology research institutions is to assist companies in the innovating process and changing paradigm (ZAMPIERI et al., 2011).

Therefore, this article aims at considering the importance of Universities as the driving force of Brazil's socioeconomic development, supporting innovation through transfer of academic experience and encouraging an entrepreneurial culture. We will also raise the importance of University technology incubators and parks and their 
DOI: 10.14807/ijmp.v5i4.208

influence in creating and developing businesses, whilst highlighting a case study from an incubator in the South of Brazil.

\subsection{Methodology}

To achieve the proposed aim, the methodology was defined on the grounds of a bibliographic survey, basically obtained through analyses of related scientific papers and materials that intend to clarify the type of work in technological incubators. Later on, meetings were held, from time to time, with the aim to come up with a pre-business plan, containing all initial information related to the ideas of the company to be set up.

The work is derived from an explanatory, descriptive research of a case study. With regard to the objectives, this research is characterized as exploratory which, according to Santos (2001), has the intention to provide more familiarity with the subject and, starting from the prospection of materials, clarifying its real importance, the stage it has reached, while revealing new sources of information. To this end, it involves a bibliographic survey and interviews with professionals of the area.

Furthermore, it is of descriptive character, once the exploratory research will serve as basis for the survey of the characteristics of the theme in question, which is considered to be a survey of the known characteristics that are part of the problem. And, according to Santos (2001), in line with the collection procedure, the research method that was adopted is also classified as case study, since it selects an object, in this case the incubation stages of an enterprise, with the aim to go deep into its characteristics.

\section{ENTREPRENEURSHIP IN BRAZIL}

Entrepreneurship may be defined as the ability to identify opportunities in relation to the creation of new processes, new products, new organizations, new businesses, and visualizing improvements, thereby generating benefits to an economy, increasing employment, wealth and its distribution. Entrepreneurship is closely linked to innovation and depends on freedom of people to create and their willingness to invent. To be able to have new insights that lead to new opportunities (FRANCO, 2005). Wennekers and Thurik (1999), when studying historical and 
INDEPENDENT JOURNAL OF MANAGEMENT \& PRODUCTION (IJM\&P)

http://www.ijmp.jor.br

v. 5, n. 4, October - December 2014

ISSN: 2236-269X

DOI: 10.14807/ijmp.v5i4.208

current influence of entrepreneurship stated that nations that promote entrepreneurship stand out in the world economic scenario.

Entrepreneurship has been expanding in Brazil since the 90's. With the introduction of the General Law of Micro and Small Enterprises in 2007 and the Law of Micro Individual Entrepreneur in 2008, entrepreneurship gains impetus (BRASIL, 2013). Governmental incentives for entrepreneurship in Brazil are being increased year after year with public notices encouraging professionals and creative entrepreneurial studies. The government has announced in 2013 that Brazilian Technical courses will encompass entrepreneurship. This incentive is the result of a partnership between the Ministry of Education and Culture (MEC) and the Brazilian Micro and Small Business Support Service (SEBRAE), aiming to reach at least 1.5 million students in Technical Education until 2014. In order to achieve this the government is also going to invest in training teachers offering scholarships in entrepreneurial education at post-graduate and masters level (ANPROTEC, 2013).

The Global Entrepreneurship Monitor research about Entrepreneurship in Brazil (GEM, 2012), which gathered information from those aged between 18 - 64 years-old in 69 countries, showed that in 2012 Brazil had around 36 million established or startup entrepreneurships representing $30.2 \%$ of the Brazilian population. It is noticeable that from 2002 to 2012 the total rate of entrepreneurship in Brazil increased almost $10 \%$. This evolution coincides with the improvement in the Brazilian economy.

Nowadays, the motivation for entrepreneurship is related to the vision of business opportunities which account for $69.2 \%$. It is a significant figure in comparison to $42 \%$ in 2002 . It shows that entrepreneurship by needs (for money) in Brazil is low.

The highest level of startup entrepreneurships in Brazil are concentrated in University educated males aged between 25 to 34 and with an income ranging from 6 to 9 times the national minimum wage (GEM, 2012). Given that the highest levels of entrepreneurship can be found amongst University educated Brazilians we describe the role of universities in Brazil as well as their contribution to society and the country (SEBRAE, 2012).

\section{UNIVERSITIES IN BRAZIL}


DOI: 10.14807/ijmp.v5i4.208

In the past decades, Brazilian universities focused mainly on passing on knowledge rather than the analysis of the subject matter. Graduation was the be all and end all. With the advent of the so-called knowledge society, Brazilian universities are being tasked to be more entrepreneurial and innovative, and therefore becoming the main player in the economic and social development of the country (ANPROTEC, 2013). Over 6.3 million students are currently attending higher education in Brazil demonstrating a staggering increase of $110 \%$ in the last decade (ANDIFES, 2013).

According to ANDIFES (2013), universities in Brazil are responsible for stimulating the creation of scientific-technological knowledge and innovation, thus raising the national standards, bringing modernization and progress. Universities therefore take on a leading role in making changes in its society increasing the country's competitiveness. According to Lamana and Kovaleski (2008), Brazilian universities are responsible for $59 \%$ of the country's patents which underlines the importance of academic knowledge transfer for the economic development of the country. We can state that the inclusion of Brazil in the world's economic stage depends fundamentally on its innovative capacity forged by universities.

Brazilian universities have been contributing to the country's economic development in several ways. We can quote some examples of research work that have reached national and international press: development of the first national fiber optics (1979), Genoma Project (2000), Ethanol Genetic Sequence (2009). Other contributions are related to research about energy use and its alternatives; environmental management; solution in information technology; solution in health such as prevention and cure of diseases (UNICAMP, 2013).

\subsection{University of Santa Cruz do Sul}

The University of Santa Cruz do Sul (UNISC) is situated in Santa Cruz do Sul being one of the engines boosting the municipality's socioeconomic development and qualifying the workforce for regional labor market.

According to UNISC (2010), it is a regional university working for its community and producing knowledge and excellence, committed to humanity freedom and to promoting regional development thereby meeting their social, cultural, educational, scientific and technological needs. 
DOI: 10.14807/ijmp.v5i4.208

The university comprises upwards of 11 thousand students, totaling 46 undergraduate courses, 37 specializations, 8 master's degree courses and $2 \mathrm{PhD}$ courses. Its staff consists of 578 professors, of which about $80 \%$ hold a master's degree or $\mathrm{PhD}$.

Being essentially a community college and considering the current economic situation in the Vale do Rio Pardo region, UNISC is strongly linked to business diversification in a region dominated by tobacco. It also plays an important part in existing commercial and services businesses.

UNISC is an university with intense academic production and by fostering entrepreneurship it is turning Santa Cruz do Sul into a technology hub. A partnership between UNISC and Ministry of Agricultural Development (MDA) has been promoting sunflower crop as an alternative to tobacco. Sunflower crop may be used for producing fuel for tractors and vehicles, being also an alternative source of energy (MULLER, 2009).

In a partnership between UNISC, the Council for Regional Development and Science and the State Department for Technology, many projects have been developed at the Technology Modernization Hub (TMP) in areas such as food, the environment, materials and information technology. TMP contributes to the development of Santa Cruz do Sul and region by developing scientific and technologic projects. An example of these is ripe seed crop which is turned into biodiesel and animal food (MULLER, 2009).

The undergraduate courses offered by the university include licentiate degrees, engineering college and computer science. All these courses are extremely important for the region and for Brazil, seeing that the IT area is now experiencing strong expansion initiatives throughout the country.

According to a survey requested by the Brazilian Association of Technology and Communication Companies - BRASSCOM, in 10 years, Brazil could become the third largest global TIC market (EPOCA, 2013).

For this to materialize, the Brazilian government intends to make huge investments during the period. Through the Major IT program, some $\mathrm{R} \$ 500$ million are to be invested by 2015 , specifically in strategic areas; mobility, supercomputing, aerospace, cloud computing, cybernetic defense, education, healthcare, petroleum 
DOI: 10.14807/ijmp.v5i4.208

and gas, finances, energy, agriculture, free software, sports events and mining operations (INFO, 2013).

Investments in this field and the rising IT market provide strong growth of startups, mainly in technological incubators.

\section{STARTUPS AND TECHNOLOGICAL INCUBATORS}

According to the Brazilian Association of Startups (ABSTARTUPS,2013), a startup can be defined as a company that is deeply based on technology, deals with innovative elements, under uncertain market conditions, and resorts to a scaling and repeatable business model.

A technology-based company, according to Junior (2012), comprises the following:

- Human capital possesses a high degree of technological knowledge;

- Is involved in research and development;

- Possesses innovative products and services, or imprints new characteristics to existing products;

- Its products have a short life cycle, due to the dynamism of innovation they carry;

- The highest costs of the product derive from the technologies and techniques used, and not specifically from the raw material they are manufactured of.

An incubator may be defined as an entity that provides entrepreneurs with the necessary technical support for the development of innovative ideas, transforming them into enterprises. To this end, it offers capacity building opportunities, management support, infrastructure, as well as guidance and commercial, financial, juridical, administrative services, among others, that are considered in the development of a company (ANPROTEC, 2012). According to branstad (2010), incubators offer a conducive space for developing business and transferring innovative technological knowledge to new enterprises, thereby strengthening business environment, industrial restructuring and jobs opportunities.

In a study conducted by the National Association of Entities that Promote Innovative Enterprises (ANPROTEC, 2012) and the Ministry of Science, Technology 
DOI: 10.14807/ijmp.v5i4.208

and Innovation (MCTI), in 2011, Brazil had a total of 384 incubators in operation, which sheltered about 2,640 companies, generating a total of almost 17,000 jobs. Moreover, about 2,500 companies graduated from these incubators which, in 2011, raked in approximately $\mathrm{R} \$ 4$ billion and employed some 30,000 people (ANPROTEC, 2012). The Figure 1 features the segments where the Brazilian incubators operate.

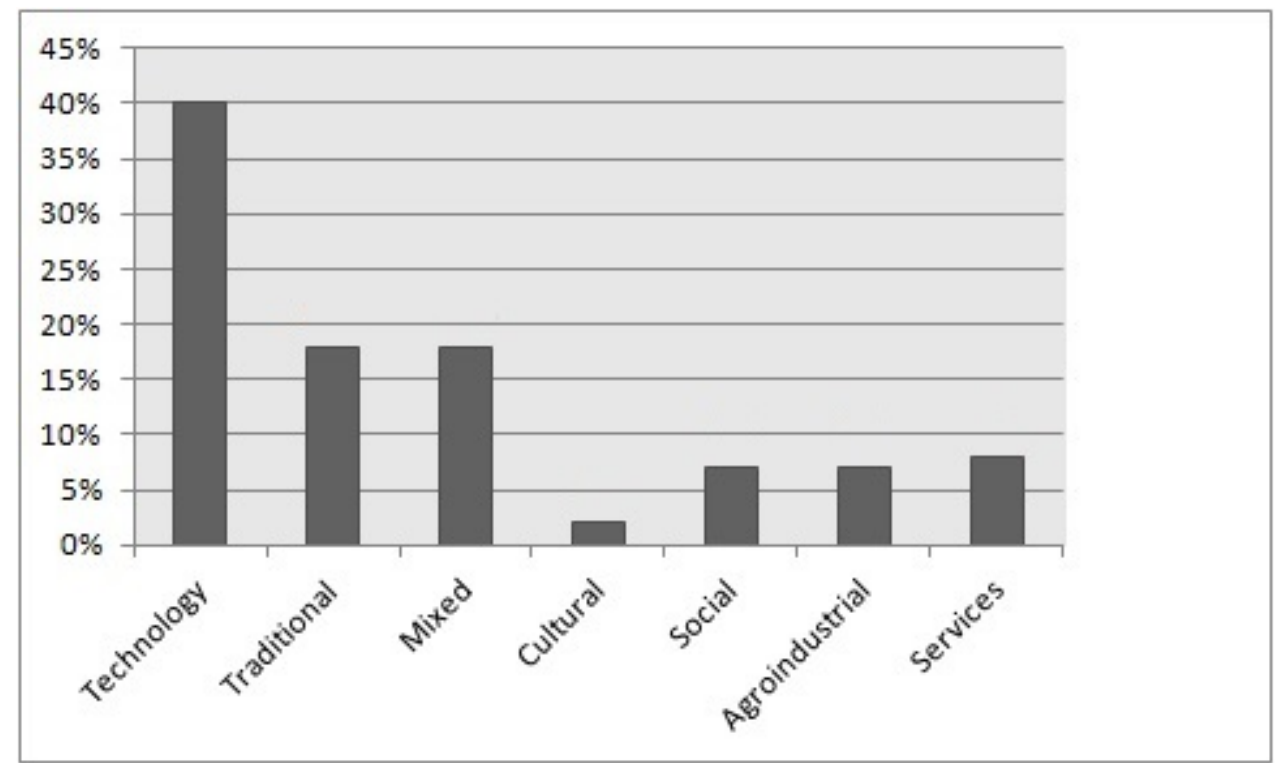

Figure 1: Areas where Brazilian incubators operate. Source: ANPROTEC, 2012.

\subsection{The role of Universities and its Incubators in fostering entrepreneurship}

Knowledge plays a key part in the new economic speculation unfolding creative ideas and innovation. The matter university-company is one of the most important issues faced by Brazilian universities and across the world.

Within this context many developed economies are increasingly augmenting knowledge transfer between Universities and industries aiming at offering real benefits to its societies. Such increase is measured by variables such as volume of funds associated with academic research and patents from universities (ROSSI, 2010). The same author reports that funding for industrial Research and Development (R\&D) is decreasing whilst R\&D in companies is being outsourced to universities. This reinforces their role in propelling economic development.

A study carried out by the author (ROSSI, 2010) reveals that companies in the United Kingdom, which are constantly innovating so as to increase their value in fast moving markets, are more likely to work alongside universities. Organizations aiming at innovation must forge an open relationship with universities, attracting new talents 
DOI: 10.14807/ijmp.v5i4.208

and forming partnerships so as to succeed in the increasingly competitive global market (BUGANZA; VERGANTI, 2009).

Zampieri et al. (2011) reveal that universities whilst knowledge producers have become more relevant to society given that knowledge is considered today the main input to economic development and new technologies. In this context, Sampaio, Nascimento and Carneiro (2005) emphasize that universities play a restructuring role in society whilst spreading knowledge and turning ideas into businesses. This is vital for stimulating the creation of new enterprises, for innovation and for long term economic growth, thus creating job opportunities and revenue.

Universities enable entrepreneurs' access by fostering entrepreneurship through its incubators. Business people are encouraged by these incubators to developing and setting up new enterprises in the market.

Sampaio, Nascimento and Carneiro (2005) believe that universities and its incubators not only encourage their students into developing innovative projects, transforming ideas into business but it also contributes to reducing death rates of employer enterprises. It promotes the development of small companies, which play an important part in least diversified economies by creating jobs and generating income and therefore improving the local economy. Statistics show that the death rate of incubated companies decreased from $70 \%$ to $20 \%$ when compared to enterprises that did not experience the incubation process (BRASIL, 2013).

We point out the following three incubators based on bibliographic research about partnerships between universities and companies and their role:

- Technological Incubator of Santa Maria (TISM): based at Federal University of Santa Maria - RS, according to Zampieri et al. (2011) was created to promote the development of Santa Maria and central region of Rio Grande do Sul state through the link between university and company, bringing benefits to the local market via knowledge transfer and innovation. Its incubation process has benefitted companies in agronomy consultancy; environmental management, information technology solutions amongst others (UFSM, 2013).

- RAIAR Incubator: based at PUC University - RS it encourages innovating and entrepreneurial work turning ideas into businesses by promoting 
INDEPENDENT JOURNAL OF MANAGEMENT \& PRODUCTION (IJM\&P)

http://www.ijmp.jor.br

v. 5, n. 4, October - December 2014

ISSN: 2236-269X

DOI: 10.14807/ijmp.v5i4.208

innovation and research. It aims at forging partnerships between researchers and companies to promote knowledge production, business network and training young entrepreneurs. Examples include companies in solar thermal energy field; software and hardware solution at industrial level; energy use, amongst others (PUC, 2013).

- Incamp Incubator: based at Campinas Regional University - SP it seeks partnership opportunities for universities and companies fostering entrepreneurship and innovation. It lends support to entrepreneurs in developing innovative technologies, benefiting its society. Such contribution is becoming increasingly more significant for the country's innovative capacity. There are incubated companies in information technology; sewage treatment, solar energy and other areas (UNICAMP, 2013).

Based on the important part that universities play in knowledge transfer, as well as promoting new markets and technologies, fostering entrepreneurships and boosting the economy via their collaborative work and incubators, we describe the role of UNISC's Technological Incubator (ITUNISC) as being the driving force for regional development.

\subsection{UNISC's Technological Incubator}

The goal of UNISC's Technological Incubator (ITUNISC), based in the city of Santa Cruz do Sul, State of Rio Grande do Sul, is to create new businesses, whilst lending support to enterprises. To this end, the Incubator offers training, consultancy, support to the creation of projects to be forwarded to fostering organs, and physical space for the establishment of companies (UNISC, 2013).

Companies incubated at ITUNISC can also take advantage of advisory programs through partnerships with the Brazilian Micro and Small Business Support Service (Sebrae), ACl (Commercial and Industrial Association), ANPROTEC (National Association of Entities that Promote Technological Parks), just to mention a few business support organs (UNISC, 2013).

The benefits derived from the use of the structure offered by ITUNISC include the following:

- There is a reduction in costs and risks of the innovation process; 
INDEPENDENT JOURNAL OF MANAGEMENT \& PRODUCTION (IJM\&P)

http://www.ijmp.jor.br

v. 5, n. 4, October - December 2014

ISSN: 2236-269X

DOI: 10.14807/ijmp.v5i4.208

- It creates strategic alliances, and facilitates access to the market;

- Generation of jobs and income for the municipality, besides promoting technological development;

- A reduction in the mortality rate of micro and small companies;

- It lends support to a new development policy for the region.

Currently, UNISC's Technological Incubator comprises seven incubated companies. Of these now incubated companies, five operate in information and communication technology, and two in other areas. Table 1, below, features the companies and their main products.

Table 1. Companies Incubated at ITUNISC

\begin{tabular}{lll}
\hline Area & Major Product & Graduated or Incubated \\
\hline Information Technology & Solutions for Internet & Graduated \\
Information Technology & Solutions for data integration & Graduated \\
Information Technology & Applications for mobile devices & Graduated \\
Information Technology & Solutions for Internet & Graduated \\
Information Technology & Development of electronic games & Graduated \\
Information Technology & Traceability and livestock certification & Incubated \\
Information Technology & Integrated logistics management & Incubated \\
Textiles & Shoe repair and customization & Incubated \\
Lighting & Production of LED based lamps & Incubated \\
Information Technology & Software quality and tests & Incubated \\
Information Technology & Traceability for meat production & Incubated \\
Information Technology & Data recovery & Incubated \\
\hline
\end{tabular}

Source: UNISC, 2013.

Besides the above mentioned partnerships, ITUNISC also counts on support from the Technology Transference and Innovation Nucleus, the NITT. The Technology Transference and Innovation Nucleus is the sector responsible for the Administration of the Institutional Policy for the Protection of Knowledge and Technology Transference, and is constantly involved with the dissemination and implementation of policies geared towards scientific and technological innovations developed at the University of Santa Cruz do Sul (UNISC), providing for incentive to the protection of creations, licenses, innovations, among others.

As an activity to be conducted at the technological park, can be cited the support to the prospection of possible partners in the entrepreneurial sector and the negotiation of partners among the agents of UNISC's productive sector, for the purpose of technology development and transference (UNISC, 2013). Through the NITT, the startup will count on the necessary support for the protection of technology 
DOI: 10.14807/ijmp.v5i4.208

to be studied and developed. Another partner is the Rio Pardo Valley Technology Modernization Hub.

The PMTVP has contributed towards the modernization of the region's productive activities through the interaction of research activities, extension services and services rendered to the University, ensuring competitiveness, through an uninterrupted flow of technological innovations, particularly in the area of Food, the Environment, Materials and Technology Information. This work is the result of joint efforts from the University of Santa Cruz do Sul, Regional Development Council, and other regional community institutions, and supported by the Rio Grande do Sul State Government, especially by the Secretariat of Science and technology and the Rio Grande do Sul Research Support Foundation (UNISC, 2013).

The role played by ITUNISC through its works and partnerships contributes to regional diversification. This diversification is highly important for Santa Cruz do Sul and most of the country's southern regions that are greatly dependent on the tobacco and cigarette market both nationally and across the world, relying on multinational companies that dominate this productive field. This economic dependence brings uncertainty and insecurity over future regional development.

IT has become urgent and necessary to promote actual work that articulate social segments of regional society and the government distinct spheres, seeking diversification for the productive chain and expanding work opportunities and income. In this context, we can point out the importance of ITUNISC in lending support and advice to the formation of micro and small businesses, thus promoting economic development, increasing revenue and creating new job opportunities, and therefore reducing local economy dependency on tobacco (UNISC, 2013). ITUNISC promotes a less dependent economy through its support and partnerships, allowing ideas to become new businesses, which in turn will create new demands and meet needs, generating new jobs and diversifying the local economy.

So far ITUNISC has had eight companies that have graduated, working at: solutions for internet where we can highlight the creation of the first Brazilian franchisor for this type of solution; advanced solutions for data integration; solutions for customized development of applications for mobile devices; electronic games development; software development for recovering lost data in hard disks and others; 
DOI: 10.14807/ijmp.v5i4.208

livestock traceability and certification; tools for processes management; integrated logistics management systems; LED lights development; amongst other graduate companies. The creation of these companies supported by ITUNISC has therefore enabled them to enter the market providing regional diversification and creating around 30 new jobs (UNISC, 2013). The incubation process for new enterprises at ITUNISC presents the following stages: pre-incubation, internal incubation and external incubation.

\subsubsection{Incubation Stages}

The pre-incubation stage comprises the structure and the idealization of the enterprise, while it is not yet operating in the market. During this stage, entrepreneurs have at their disposal technical consultancies specialized in the areas they have opted for, besides consultancy services in management, administrative and accounts areas. They can also take advantage of UNISC's structure for planning meetings, and they have access to the research labs and learning facilities of the university.

To take part in the external incubation, the entrepreneurs need to come up with a pre-business plan, which does not require the level of detail of a definitive business plan but must contain sufficient information for the evaluation board to get a good knowledge of products and services the startup intends to develop and the manner it wishes to operate in the market.

The pre-incubation stage lasts for a maximum of six weeks. During this period, the incubated company concludes the maturation of the business, evaluating the competitors and defining its main products, production planning and the tools to be used, among other details to be taken into consideration. During this stage, the preincubated company does not use the incubator's physical space.

At the end of the pre-incubation stage, its partners may take the company to incubation, where there are two options: internal or external incubation.

During the internal incubation time, the company conducts the implementation of the business plan which was worked out during the pre-incubation stage, using for this purpose the infrastructure provided by ITUNISC, like physical space, electric energy, access to the internet, consultancy rooms, training, meeting rooms, audiovisual equipment, publicity services, among others. Maximum period for internal incubation is 24 months, with chances for a 12-month renewal. 
DOI: 10.14807/ijmp.v5i4.208

External incubation is very similar to internal incubation, but in the first case the incubated company is not allowed to take advantage of the physical space that is offered by ITUNISC. Therefore, the externally incubated company operates in a space of its own.

\section{PRE-INCUBATION STUDY CASE OF A STARTUP}

In this topic, the focus is on the stages performed in order to direct the preincubation stage of a startup to UNISC's Technological Incubator.

\subsection{Idealization of the startup}

The motivation to create the startup surfaced during the undergraduate course of the partners, both with a degree in computer science from the University of Santa Cruz do Sul (UNISC). The formalization of all major products and the development of the business plan were effectively conducted during the master's degree course, again by the two partners.

These products and solutions were based on projects developed in class, as well as in undergraduate course conclusion works and master's degree dissertation projects. These products were modulated with an eye towards potential market niches poised to be explored in Brazil and in the global scenario.

To this end, advanced computer techniques are to be used, like image processing, voice processing, embedded systems and software directed towards handheld devices. Through the definition of these techniques to be utilized in product development, was distinguished the startup from the companies that commonly focuses on systems for small and medium scale entrepreneurial administration, commercial automation and the development of web-sites and blogs. Moreover, through the definition of these technologies to be utilized in the productive process of the startup, it can be possible guide the companies toward very specific market niches.

Another important topic about the products to be developed by the startups is that they do not have any qualification that makes them eligible for being inserted into some type of automation that could reduce the number of people employed. The products projected up to that time are only aimed at exploring new chances of business representations, as well as new manners of executing services utilizing 
DOI: 10.14807/ijmp.v5i4.208

technology as an intermediate element, especially in social areas where computation is used in multidisciplinary topics.

The use of complex computation techniques and technologies was also defined with the aim to qualify the startup to act as partner for all other companies that might wish to utilize services for research and development of products and solutions.

It is also important to mention the existence of entrepreneurship disciplines in the undergraduate course. Specifically at UNISC's Computer Science course, the Entrepreneurship Computer Science discipline is offered in the 10th semester, when the students begin to learn about concepts and experiences in business modeling, where the evaluation work consists in the development of an imaginary business plan in the IT area.

To obtain the necessary qualification to take part in the evaluation board of UNISC's Technological Incubator, some steps were followed, and they are detailed below.

\section{2}

\section{Application steps for proposing the creation of a startup}

First of all, there was a need for coming up with a pre-business plan. In this pre-plan, the partners of the company had to describe some topics requested by UNISC's Technological Incubator for the evaluators to learn about the business and get a grasp of the potential chances of the startup to explore the market.

For elaborating the pre-business plan, the knowledge acquired in the discipline Entrepreneurship in Computer Science was utilized, greatly facilitating the written words and the ideas about the startup. Once the pre-business plan had materialized, there was a need to collect some identification documents of the partners, their curricula, and the collection of the enrolment fee. Afterwards, the necessary documentation was forwarded and an evaluation board was put on the agenda.

The final step in the process of forwarding the proposal for the startup was the evaluation board. According to UNISC (2013), the evaluation step consists, basically, in verifying if the proposed enterprise achieves the following topics:

- Viability of the enterprise (technical, economic and marketwise);

- Managerial and technical capacity of the entrepreneurs; 
INDEPENDENT JOURNAL OF MANAGEMENT \& PRODUCTION (IJM\&P)

http://www.ijmp.jor.br

v. 5, n. 4, October - December 2014

ISSN: 2236-269X

DOI: 10.14807/ijmp.v5i4.208

- Content in the enterprise (managerial, technological and innovative);

- Possibility of interacting with UNISC's activities;

- Technical team of the company;

- Respect to timeframes and participation manners;

- Adjustment and compliance with ITUNISC's Objectives.

The evaluation board, or the Technical Selection Committee, was composed of representatives of the following organs: UNISC, municipality of Santa Cruz doSul, entrepreneurial associations, entrepreneur support entities and ITUNISC guests. All major products and services to be developed, idealized by the partners, were presented to this committee. By unanimity, the board identified that the products in question had a huge market exploration potential, giving their approval to the preincubation of the startup.

At this moment, its partners are engaged in a deep study of the market, its potential clients, competitors, and production planning. Soon, they will take courses offered by ITUNISC for enhancing their business administration capacity, as well as contact with consultancies for company design and maturation.

\section{CONCLUSION}

Nowadays, subjects related to entrepreneurship, innovation, universities' role and its incubators as the driving force to economic development have been highly regarded in the world's economic stage, even featuring as a differential in economic competitiveness. Therefore, we note that Brazil has evolved immensely presenting an unrivalled growth in entrepreneurship (FAAP, 2013).

Brazilian universities have been working hard with regards to knowledge transfer. They have been developing solution-based projects using innovative technology benefiting the society. These projects have been distinguished nationally and internationally. Entrepreneurial culture is highly valued by Brazilian universities through its incubators, transforming ideas into businesses.

This knowledge production and transfer by universities through partnerships between companies and incubators has strengthened our country's economy. New jobs have been created by supporting new enterprises; better income distribution; 
DOI: 10.14807/ijmp.v5i4.208

competitiveness has increased both nationally and internationally and stimulus to innovation. Therefore Brazilian universities have strengthened themselves as the driving force of the socioeconomic progress.

In this context, the University of Santa Cruz do Sul (UNISC) and its Technological Incubator (ITUNISC) have been exemplary and instrumental in turning Santa Cruz and its region into a technological hub. Continuing on the same subject, UNISC is planning the launch a Technological Park: TechnoUnisc. It is under construction and it will provide an environment for production and technology management. The new park will also be a conductive place to develop technologybased enterprises, innovative and entrepreneurial businesses.

\section{ACKNOWLEDGMENT}

This research was supported by the UNISC (FAP and IC). Also, the authors thank the CAPES agency for the support in the survey.

\section{REFERENCES}

ABSTARTUPS (2013). O que é uma startup. Available at: <http://www.abstartups.com.br/o-que-e-uma->. Startup. Accessed in January, 2013.

ANDIFES (2013). Dois universos. Available at: <http://www.andifes.org.br>. Acessed in september, 2013.

ANDIFES (2013). O novo ambiente do ensino superior. Available at: $<$ http://www.andifes.org.br>. Acessed in september, 2013.

ANPROTEC (2013). Incubadoras e parques. Available at: <http://anprotec.org.br/site/incubadoras-e-parques>. Accessed in January, 2013.

ANPROTEC (2013). É tempo de acelerar. Available at: <http://issuu.com/portomediterraneo/docs/locus72_anprotec_site>. Acessed in september, 2013.

BIRGITTA, SANDBERG; HURMERINTA, LEILA; ZETTINIG, PETER (2013). Highly innovative and extremely entrepreneurial individuals: what are these rare birds made of?, European Journal of Innovation Management, v. 16, n. 2, p.227-242.

BRANSTAD, ARE (2010). A study of management tasks and stakeholders in a hybrid corporate incubator. European Journal of Innovation Management, v. 13, n. 3 , p.294-312.

BRASIL. (2013) Empreendedorismo hoje. Available at: http://www.brasil.gov.br/empreendedor/empreendedorismo-hoje. Acessed in September, 2013.

BUGANZA, TOMMASO; VERGANTI, ROBERTO (2009). Open innovation process to inbound knowledge: Collaboration with universities in four leading firms. European Journal of Innovation Management, v. 12, n. 3, p.306- 325. 
EPOCA (2013). Brasil pode ser $3^{\circ}$ maior mercado de TI, prevê estudo. Available at:

http://epocanegocios.globo.com/Informacao/Visao/noticia/2012/10/brasil-pode-ser-3maior-mercado-de-ti-preve-estudo.html. Accessed in December, 2012.

FAAP. (2013) Empreendedorismo: a revolução do novo Brasil. Available at: http://www.faap.br/revista_faap/rel_internacionais/empreendedorismo.htm. Acessed in october, 2013.

FRANCO, AUGUSTO DE (2013). Empreendedorismo político. Available at: http://200.252.248.103/sites/revistasebrae/01/artigo2.htm. Acessed in october.

FRANCO, MARIO; HAASE, HEIKO (2013). Firm resources and entrepreneurial orientation as determinants for collaborative entrepreneurship. Management Decision, v. 51, n. 3, p.680 - 696.

GEM - Global Entrepreneurship Monitor (2012). Empreendedorismo no Brasil. RelatórioGlobal.

INFO (2013). Governo anuncia plano de $\mathbf{R} \mathbf{4 8 6} \mathbf{~ m i ~ d e ~ r e a i s ~ p a r a ~ a ~ i n d u ́ s t r i a ~ d e ~}$ TI. Available at: <http://info.abril.com.br/noticias/mercado/governo-anuncia-plano-der-486-mi-de-reais-para-a-industria-de-ti-20082012-17.shl>. Accessed in March, 2013.

JUNIOR, Pedro Paulo de Andrade (2012). The Brazilian Experience In Overcoming Dificulties of Technology-Based Companies in Incubators. Journal of Technology Management \& Innovation. v.7, n. 3.

LAMANA, SERGIO; KOVALESKI, JOÃO LUIZ (2013). Patentes e o desenvolvimento econômico. Available at:

<http://www.convibra.com.br/upload/paper/adm/adm_1518.pdf>. Acessed in september, 2013.

MATíZ, F. J; NARANJO, G. F (2010). La Financiación De Nuevas Empresas En Colombia, Una Mirada Desde La Demanda. Enero-Junio: Bogotá.

MULLER, IGOR (2009). Revista Santa Cruz do Sul um Polo de Oportunidades. Santa Cruz do Sul: Gazeta Santa Cruz.

PUC (2013). Raiar PUC: Ponha seus projetos em prática. Available at: http://www.pucrs.br/raiar/. Acessed in september, 2013.

ROSSI, FEDERICA (2010). The governance of university-industry knowledge transfer. European Journal of Innovation Management, v. 13, n. 2, p.155-171, 2010.

SAMPAIO, LUCIANA LEAL; TEIXEIRA, ANDERSON ROBERTO NASCIMENTO; CARNEIRO, MARIANA PEREIRA; FRANÇA, VILCIANE DE OLIVEIRA (2013). 0 estímulo ao empreendedorismo na universidade: o caso da pré-incubação da Rede de Incubadoras de Tecnologia da Universidade do Estado do Pará.

Available at:

http://www.abepro.org.br/biblioteca/ENEGEP2005_Enegep1103_0950.pdf. Acessed in September, 2013.

SANTOS, ANTONIO RAIMUNDO DOS (2001). Metodologia científica: a construção do conhecimento. 4. ed. Rio de Janeiro: DP\&A, 2001. 139 p. 
DOI: 10.14807/ijmp.v5i4.208

SEBRAE (2013). Empreendedorismo no Brasil. Available at: http://www.sebrae.com.br/uf/pernambuco/downloads/estudos-epesquisas/copy3_of_seminario-web/pesquisa-gem-2012.pdf. Acessed in september, 2013.

UFSM (2013). Empresas residentes. Available at:

http://coral.ufsm.br/itsm/index.php/empresas/residentes. Acessed in September, 2013.

UNICAMP (2013). Reitor da Unicamp recebe título de Cidadão Campineiro. Available at: http://www.unicamp.br/unicamp/. Accessed in September.

UNICAMP (2013). Empresas Incubadas. Available at:

http://www.inova.unicamp.br/incubadora/incubadas\#. Acessed in september, 2013.

UNISC (2013). Projeto do Parque Científico e Tecnológico. Santa Cruz do Sul: UNISC. Restricted access, 2013.

UNISC (2013). Núcleo de Inovação e Transferência de Tecnologia. Available at: http://www.unisc.br/portal/pt/pesquisa/nitt/11/nucleo-de-inovacao-e-transferencia-detecnologia--nitt.html. Accessed in Fabruary, 2013.

UNISC (2013). Pólo de Modernização Tecnológica do Vale do Rio Pardo. Available at: http://www.unisc.br/portal/pt/a-unisc/areas/setores/54/polo-demodernizacao-tecnologica-do-vale-do-rio-pardo-.html. Accessed in Fabruary, 2013.

UNISC (2013). Incubadora Tecnológica. Available at:

http://www.unisc.br/portal/pt/aunisc/areas/setores/47/incubadora-tecnologica-.html. Acessed in september, 2013

VIANA, RODRIGO BAHIA CERQUEIRA (2012). A Estratégia Na Incerteza: Explorando Cenários Para Empresas Recém-Criadas No Mercado Brasileiro De Tecnologia Da Informação. REUNA: Belo Horizonte, Brasil, v. 17, n. 3, p. 85-98.

ZAMPIERI, N. L. V.; SANTINI, S.; PINTO, C. O. F.; RUPPENTHAL, J. E. (2011). Empreendedorismo De Base Tecnológica E Desenvolvimento Regional: Um Estudo De Caso Na Incubadora Tecnológica De Santa Maria. XXXI Encontro Nacional De Engenharia De Produção Inovação Tecnológica E Propriedade Intelectual: Desafios da Engenharia de Produção na Consolidação do Brasil no Cenário Econômico Mundial. Belo Horizonte, October, 2011.

WENNEKERS, S.; THURIK, R (1999). Linking Entrepreneurship and Economic Growth. Small Business Economics. Rotterdam Netherlands.: v. 13, p. 27-55, 1999. 